\title{
Biological control in the germination of seeds from two species native of the Cerrado region
}

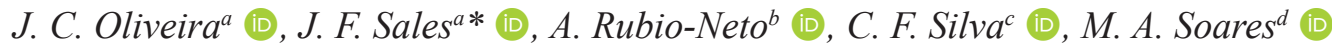 \\ and F. G. Silva ${ }^{b}$ \\ a'Laboratório de Sementes, Instituto Federal Goiano - IF Goiano, Campus Rio Verde, Av. Sul Goiana, Km 01, Zona Rural, \\ CEP 75900-000, Rio Verde, GO, Brasil \\ 'Laboratório de Cultura de Tecidos Vegetal, Instituto Federal Goiano - IF Goiano, Campus Rio Verde, Av. Sul Goiana, \\ Km 01, Zona Rural, CEP 75900-000, Rio Verde, GO, Brasil \\ 'Laboratório de Microbiologia Agrícola, Instituto Federal Goiano - IF Goiano, Campus Rio Verde, Av. Sul Goiana, \\ Km 01, Zona Rural, CEP 75900-000, Rio Verde, GO, Brasil \\ 'Instituto de Biociências, Universidade Federal de Mato Grosso - UFMT, Av. Fernando Corrêa da Costa, 2367, \\ Boa Esperança, CEP 78060-900, Cuiabá, MT, Brasil \\ *e-mail: juliana.sales@ifgoiano.edu.br
}

Received: April 4, 2019 - Accepted: September 20, 2019 - Distributed: February 28, 2021

(With 2 figures)

\begin{abstract}
Microorganisms have been efficiently used for the biological control of phytopathogens through the production of antimicrobial substances. However, the objectives of this work were: to study the germination of Butia purpurascens Glassman and Butia archeri Glassman seeds in different substrates, to select and identify the endophytic and rhizospheric bacterial isolates of B. purpurascens and B. archeri, and to perform antibiosis tests based on the isolated microorganisms of these tree species. No difference was found between the cultivation substrates for the percentages of germination, hard seeds, and fungal contamination in the B. purpurascens seeds. The Bacillus subtilis isolated showed the best capacity for suppressing the growth of the two deteriorative fungi tested in B. purpurascens seeds. No difference was found for inhibition of the growth of Aspergillus niger fungus (deteriorative fungus of $B$. archeri seeds) between the microorganisms with Bacillus sp. and Brevibacillus brevis compared to the control. In the microbiolization of $B$. purpurascens and $B$. archeri seeds performed with microbiological solutions produced from the endophytic and rhizospheric strains of Bacillus sp., no differences were observed in the percentages of germination and contamination by fungi. For $B$. archeri seeds, there was contamination by fungi and bacteria after one day of cultivation, primarily in the regions with lesions caused by the extraction and scarification process.
\end{abstract}

Keywords: antibiosis, microbiolization, endophytics, physical dormancy.

\section{Controle biológico na germinação de sementes de duas espécies nativas da região do Cerrado}

\section{Resumo}

Microorganismos específicos tem sido usados eficientemente para o controle biológico de fitopatógenos através da produção de substâncias antimicrobianas. Portanto, os objetivos deste estudo foram: estudar a germinação de sementes de Butia purpurascens Glassman e Butia archeri Glassman em diferentes substratos; selecionar e identificar isolados bacterianos rizosféricos e endofíticos de B. purpurascens e B. archeri, e realizar testes de antibiose a partir de microorganismos isolados dessas espécies arbóreas. Não houve diferença entre os substratos de cultivo para as porcentagens de germinação, de sementes duras e de contaminação por fungos nas sementes de B. purpurascens. O isolado bacteriano Bacillus subtilis apresentou melhor capacidade de supressão do crescimento dos dois fungos deterioradores testados nas sementes de B. purpurascens. Não foi encontrada diferença para a inibição do crescimento do fungo Aspergillus niger (fungo deteriorador de sementes de B. archeri) entre os microorganismos com Bacillus sp. e Brevibacillus brevis em comparação ao controle. Na microbiolização das sementes de B. purpurascens e B. archeri realizada com soluções microbiológicas produzidas a partir de cepas endofíticas e rizosféricas de Bacillus sp. não foram observadas diferenças na porcentagem de germinação e contaminação por fungos. Para $B$. archeri houve contaminação por fungos e bactérias após um dia de cultivo, principalmente nas regiões de lesão proporcionadas pelo processo de extração e escarificação.

Palavras-chave: antibiose, microbiolização, endofíticos, dormência física. 


\section{Introduction}

It is estimated that the Brazilian Cerrado contributes 10,000 plant species of the 60,000 phanerogams distributed across the country, marking this region as the richest in terms of flora diversity among the savannas of the world. It includes countless medicinal, ornamental, and fruit-bearing species that are important to the local populations (Gusmão et al., 2006) and is also considered one of the "hotspots" for global biodiversity conversation (Myers et al., 2000).

In this study, we used two plant species of great importance from the Cerrado region, Butia purpurascens Glassman and Butia archeri Glassman, both belongings to the family Arecaceae, popularly known as purple yatay palm and dwarf jelly palm, respectively. These species have great potential in ornamental, culinary applications owing to the flavor and fragrance of their fruits (Lorenzi et al., 2010), and in the therapeutic treatment of skin diseases (Hoffmann et al., 2014).

Species from the genus Butia are classified as critically endangered, with an estimated reduction in the population of over $80 \%$ over the next 10 years. As it is native to the southern region of Goias and the northern region of the Minas Gerais Triangle, it competes for land with soy and sugarcane plantations, further exacerbating the extinction process. Seeds of these species have a high rate of contamination by microorganisms during the pre- and post-emergence processes, resulting in the formation of abnormal seedlings and root rot (Magalhães et al., 2008; Bozza, 2009; IUCN, 2011).

Members of the family Arecaceae reproduce largely through sexual reproduction. Owing to the lengthy duration and low germination efficiency, phytoregulators must be applied and/or procedures must be adopted that facilitate the absorption of water, such as mechanical scarification. Although scarification can accelerate and increase the percentage of germination, the resulting wounds become an entry point for harmful microorganisms, which hinder or impede germination, resulting in a significant reduction in the number of viable plants (Rubio Neto et al., 2012, 2014).

The use of specific microorganisms for the biological control of phytopathogens has proven to be efficient against certain fungi and bacteria owing to the production of antimicrobial substances (Rocha et al., 2009; Yuan et al., 2017; Saito et al., 2018; Liu et al., 2018), which leads to an alternative to the chemical control of diseases. These biological control agents can act directly and indirectly by inducing the plant's defense mechanisms in the control of fungal diseases (Benítez et al., 2004).

The interactions between pathogenic microorganisms and their antagonists include antibiosis, competition, parasitism, predation, and induction of the host's defenses (Melo and Azevedo, 1998). Most of the microorganisms involved in biological control operate by means of antibiosis, in which a metabolite produced by one microorganism has a harmful effect on the other, thereby inhibiting its growth. The production of metabolites may result in complete lysis and dissolution of the cellular structure, regardless of physical contact between the microorganisms (Remuska and Pria, 2007).

The objective of this study was to determine the best germination environment for B. purpurascens and B. archeri, identifying the deteriorative microorganisms infecting their seeds, and testing the ability of bacteria isolated from these tree species to control these microorganisms.

\section{Material and Methods}

\subsection{Obtaining the seeds}

The study was carried out at the Federal Institute of Education, Science, and Technology of Goias - Rio Verde Campus, GO, in partnership with the Seeds, Plant Tissue Culture, and Agricultural Microbiology laboratories. The fruits of Butia purpurascens and Butia archeri were collected, respectively, 17³5'10.51'S, 5059'13.06”'W, $822 \mathrm{~m}$ and $17^{\circ} 35^{\prime} 10.51^{\prime \prime} \mathrm{S}, 50^{\circ} 59^{\prime} 13.06^{\prime \prime} \mathrm{W}, 822 \mathrm{~m}$, in the city of Rio Verde, GO. The two species were intercropped with pasture and their fruits were randomly collected.

The fruits were pulped to obtain the diaspores and, subsequently, the seeds were extracted using a bench vise. The extracted seeds were disinfected in $70 \%$ alcohol for 1 minute and $40 \%$ sodium hypochlorite for 4 minutes. Next, they were washed in distilled water and autoclaved three times. Mechanical scarification was carried out in the laminar flow, removing the tegument in the hilar region (Rubio Neto et al., 2014). The phytosanitary and germination evaluations of the $B$. purpurascens and $B$. archer $i$ seeds were performed according to the experimental tests described below.

\subsection{Germination of B. purpurascens seeds in different substrates}

Three germination substrates were evaluated: rolls of Germitest ${ }^{\circledR}$ paper, glass plates $(120 \times 150 \mathrm{~mm})$ covered with washed and autoclaved sand, and Germitest ${ }^{\circledR}$ paper. On the plates containing sand, a field capacity of $60 \%$ was maintained weekly, while the paper was moistened with distilled autoclaved water in the amount of 2.5 times the weight of this dry substrate.

The seeds were kept in a Mangelsdorf germinator set at $30{ }^{\circ} \mathrm{C}$ for 30 days. The experiment used a completely randomized design, with seven repetitions of three germination substrates. The test was evaluated on a daily basis. When contamination by fungi or bacteria was detected, the contaminated seeds were removed from the germination environment and taken to the Laboratory of Agricultural Microbiology for identification and antibiosis tests. After 30 days, we evaluated the percentages of germination, contamination by fungi and bacteria, and hard seeds, the latter of which is characterized by the absence of contamination and germination. Only seeds with a cotyledon petiole of at least $1 \mathrm{~cm}$ in length were considered germinated.

Next, the data normality and the homogeneity of the variances were evaluated through the Shapiro-Wilk and 
Bartlett tests $(5 \%)$, respectively, and the averages were compared by the Tukey's test (5\%).

\subsection{Selection of the endophytic and rhizospheric bacterial isolates of Butia purpurascens and Butia archeri}

One hundred and fifty-three bacteria (67 endophytics from roots and 86 rhizospherics) were isolated from $B$. purpurascens and 110 bacteria were isolated from B. archeri (22 endophytics and 88 rhizospherics). Next, a qualitative test was performed on a Petri dish, containing PDA culture medium (infusion of $200 \mathrm{~g}$ of potatoes, $200 \mathrm{~g}$ of dextrose and $15 \mathrm{~g}$ of agar), in which four bacterial isolates were inoculated in the center of the plate opposite the fungal isolate. Bacteria that impeded the normal growth of the fungal mycelium were considered antagonistic when compared to the control plate, which was inoculated only with the fungal isolate.

\subsection{Antibiosis test}

To quantify the degree of antagonism of the seed-deteriorating microorganisms, we selected eight bacteria (seven rhizospherics and one endophytic) isolated from the species $B$. purpurascens, and two bacteria (one rhizospheric and one endophytic) from $B$. archeri. The tests were performed according to the dual culture method (Mew and Rosales, 1986).

After the seed-deteriorating fungi were isolated, those that appeared with the greatest frequency were selected. For B. purpurascens, the fungal species Neodeightonia phoenicum BP91DF and Penicillium purpurogenum BP110DF were selected, while Aspergillus niger $\mathrm{BA} 163 \mathrm{D}$ was isolated from $B$. archeri seeds. The fungi were multiplied in PDA culture medium for a period of seven days. Next, the fungal mycelium was inoculated in the center of the Petri dish. Neodeightonia phoenicum BP91DF and A. niger BA163DF were distanced $3 \mathrm{~cm}$ apart with immediate inoculation of the potential antagonists on opposite sides. The fungus P. purpurogenum BP110DF, owing to its slow growth, was inoculated 48 hours in advance, distanced $2 \mathrm{~cm}$ apart.

The experiment used a completely randomized design, with three repetitions for each fungus. The plates were incubated at room temperature for 4 to 8 days, depending on the speed of fungal growth. The diameter of the fungus was measured with a caliper, and the zone of fungal growth inhibition owing to the production of suppressive compounds by the bacteria was noted.

\subsection{Identification of the microorganisms}

The bacteria that expressed some capacity for antagonism and the seed-deteriorating fungi that were isolated were submitted for molecular identification. The bacteria were identified based on $16 \mathrm{~S}$ rDNA, and the fungi were identified through partial sequencing of the internal transcribed spacer (ITS) from the rDNA region taken from one representative of each morphotype group.

Total genomic DNA of the purified bacteria was extracted using the method proposed by Cheng and Jiang (2006). The 16s rDNA gene was amplified using the primers 27F (5'-AGA GTT TGA TCM TGG CTCAG-3') and 1492R (5'-TAC GGY TAC CTT GTT ACG ACT T-3') (Weisburg et al., 1991). PCR was performed in a total volume of $25 \mu \mathrm{L}$, containing $1 \mu \mathrm{L}$ of DNA extract, $17.45 \mu \mathrm{L}$ of ultra-pure water, $2.5 \mu \mathrm{L}$ of PCR $10 \mathrm{x}$ buffer, $0.75 \mu \mathrm{L}$ of $\mathrm{MgCL}_{2}, 2 \mu \mathrm{L}$ of $\mathrm{dNTP}, 1 \mu \mathrm{L}$ of $27 \mathrm{~F}$ primer, $1 \mu \mathrm{L}$ of $1492 \mathrm{R}$ primer, and $0.3 \mu \mathrm{L}$ of the Taq polymerase enzyme (Invitrogen ${ }^{\circledR}$ ). The amplification conditions were performed as follows: initial denaturation at $94^{\circ} \mathrm{C}$ for $2 \mathrm{~min}$; followed by 30 cycles of $94^{\circ} \mathrm{C}$ denaturation for $40 \mathrm{sec}$, annealing at $58^{\circ} \mathrm{C}$ for $35 \mathrm{sec}$, and elongation at $72^{\circ} \mathrm{C}$ for $1 \mathrm{~min} 20 \mathrm{sec}$; and a final extension at $72^{\circ} \mathrm{C}$ for $10 \mathrm{~min}$.

The fungal isolates were grown in a liquid PD medium (400 $\mathrm{mL}$ of potato infusion, $20 \mathrm{~g}$ of dextrose) at room temperature for seven days. The fungal mycelium was washed in distilled water using a sieve to remove all the culture medium. Next, the sample was dried with a paper towel to remove moisture and placed in the freezer at $-20{ }^{\circ} \mathrm{C}$ until the analysis.

The genomic DNA of the fungi was extracted using a DNA extraction kit, following the manufacturer's recommendations (Axygen Biosciences, USA). Morphotyping was carried out by analyzing the genetic variability of the ISSR (Inter Simple Sequence Repeat Amplification) and IRAP (Inter Retrotransposon Amplified Polymorphism) molecular markers.

The identification was performed through partial sequencing of the internal transcribed spacer (ITS) of the rDNA region of representatives of each morphotype group. The oligonucleotides ITS 4 (5' -TCC TCC GCT TAT TGA TAT GC-3') and ITS 5 (5'-GGA AGT AAA AGT CGT AAC AAG G-3') (White et al., 1990) were used to amplify the $18 \mathrm{~S}$ to $28 \mathrm{~S}$ intergenic region. The reaction mixture of $35 \mu \mathrm{L}$ contained $22.35 \mu \mathrm{L}$ of ultra-pure water, $3.5 \mu \mathrm{L}$ of 10x PCR buffer, $1.5 \mu \mathrm{L}$ of $\mathrm{MgCL}_{2}, 2.8 \mu \mathrm{L}$ of dNTP, $1 \mu \mathrm{L}$ of ITS 4 primer, $1 \mu \mathrm{L}$ of ITS5 primer, and $0.3 \mu \mathrm{L}$ of the Taq polymerase enzyme. The amplification conditions were performed in an AmpliTherm Thermal Cycler as follows: initial denaturation at $94{ }^{\circ} \mathrm{C}$ for $2 \mathrm{~min} ; 35$ cycles of $94{ }^{\circ} \mathrm{C}$ denaturation for $45 \mathrm{sec}$, annealing at $50{ }^{\circ} \mathrm{C}$ for $45 \mathrm{sec}$, and elongation at $72{ }^{\circ} \mathrm{C}$ for $1 \mathrm{~min}$; and the final extension at $72{ }^{\circ} \mathrm{C}$ for $10 \mathrm{~min}$.

The amplification products of the gene 16S (bacteria) and the ITS region (fungi) were purified according to Dun and Blattner (1987). To quantify the DNA, $1 \mu \mathrm{L}$ of the product was loaded into a $0.8 \%$ agarose gel for gel electrophoresis. The sequencing was performed using the Sanger method with a Big Dye Kit on an ABI 3100 (Applied Biosystems). The sequences were compared in the GenBank database (NCBI, 2019) against known sequences through a search for similarity using BLASTN.

\subsection{Microbiolization of the Butia purpurascens and Butia archeri seeds}

The bacteria were selected according to the best results on the antibiosis test. To prepare the bacterial suspensions, the isolates were cultivated in a nutrient broth medium ( $3 \mathrm{~g}$ meat extract, $5 \mathrm{~g}$ peptone) separately for 24 hours. 
After this period, the concentration of the inoculation was adjusted to $\mathrm{OD}_{600}=0.1$ with a sterilized saline solution $(0.85 \mathrm{NaCl})$.

The seeds were submerged in a $\mathrm{GA}_{3}\left(200 \mathrm{mg} \mathrm{L}^{-1}\right)$ solution for 48 hours in a germinator set to $30^{\circ} \mathrm{C}$ and then submerged for $30 \mathrm{~min}$ in bacterial inoculants. For the Butia purpurascens seeds, the following microorganisms were used: control (nutrient broth), the rhizospheric bacteria Bacillus amyloliquefaciens BP1RB, B. amyloliquefaciens BP70RB, B. subtilis BP186RB, and B. methylotrophicus BP35EB (endophytic). For Butia archeri, seeds taken from the Bacillus sp. BA68EB (endophytic) and Brevibacillus brevis BA89R (rhizospheric) and the control were used.

Once removed from the inoculum, the seeds were placed on glass plates $(120 \times 150 \mathrm{~mm})$ containing Germitest $^{\circledR}$ paper to germinate. These were moistened with autoclaved distilled water in the amount of 2.5 times the weight of this paper and kept in a Mangelsdorf germinator set to $30{ }^{\circ} \mathrm{C}$ for 30 days.

The experiment used a completely randomized design with five repetitions each. The percentages of germination, contamination by fungi and bacteria, and hard seeds were evaluated. The averages were compared through the Tukey's test (5\%).

\section{Results}

\subsection{Germination of Butia purpurascens seeds in different substrates}

There was no difference between the cultivation for the $B$. purpurascens seeds in terms of the percentages of germination, hard seeds, and contamination by fungi (Table 1). A difference between the germination substrates was observed only in the percentage of contamination by bacteria: the glass plate with Germitest ${ }^{\circledR}$ paper yielded the least contamination by bacteria at only $0.8 \%$ (Table 1 ).

We highlight that the contamination occurred mainly near the lesions during seed extraction and scarification, which may have served as a gateway for saprophytic microorganisms (fungi and bacteria), and possibly reduced the germination rates of the species in these substrates.

\subsection{Identification of the microorganisms}

The grouping of the fungal isolates from seeds of the three evaluated cultivation substrates into morphotypes indicated the presence of 17 groups for B. purpurascens, totaling 67 fungi and, for $B$. archeri, 10 groups with 40 fungi. These were distinguished by macroscopic characteristics. After molecular identification of one representative of each group through the amplification profile of the molecular marker ISSR and/or IRAP of the different strains (data omitted), identical profiles could be detected, enabling taxonomic identification.

At the species level, an identity above $97 \%$ of the ITS region was used as a criterion of similarity (O'Brien et al., 2005).

For B. purpurascens seeds, this study revealed the association of fungi only from the phylum Ascomycota, from which three classes were identified: Eurotiomycetes (64.2\%), Sordariomycetes (20.9\%), and Dothideomycetes (14.9\%). These were distributed across 10 genera: Aspergillus (28.4\%); Penicillium (25.4\%); (Table 2). For B. archeri, there was also a predominance of members of the phylum Ascomycota, and 40 taxons from three classes were identified: Eurotiomycetes (82.5\%), Sordariomycetes $(12.5 \%)$, and Dothideomycetes (5\%), distributed across seven genera, predominated by Aspergillus (67.5\%); Gibberella, Penicillium and Talaromyces (7.5\%), and Fusarium and Neodeightonia (5\%), as shown in Table 3.

The antagonistic bacteria selected and identified were exclusively of the genus Bacillus, and of the species amyloliquefaciens, brevis, methylotrophicus, and subtilis (Table 4). Members of this genus are commonly found in environments with soil and water. Some of its species have antifungal activity against plant pathogens and are capable of inhibiting mycelial growth and the germination of conidia, and thus play important roles in the infection cycle of pathogenic agents (Song et al., 2014).

\subsection{Antibiosis}

For Butia purpurascens, the deteriorative fungus $N$. phoenicum BP91DF seeds were inhibited by the rhizospheric bacteria $B$. amyloliquefaciens BP1RB and B. subtilis BP186RB (Figure 1 and Table 5).

The fungus $P$. purpurogenum BP110DF was inhibited by the isolates $B$. amyloliquefaciens $\mathrm{BP} 1 \mathrm{RB}, \mathrm{BP} 66 \mathrm{RB}$, $\mathrm{BP} 70 \mathrm{RB}$, and BP201RB (rhizospheric); B. subtilis BP60RB and BP186RB; and B. methylotrophicus BP35EB (endophytic). The rhizospheric bacterial isolates of B. amyloliquefaciens BP1RB and B. subtilis BP186RB showed the highest capacity for suppressing the growth of the Neodeightonia phoenicum BP91DF (Table 5). The action of the bacteria were similar for the fungus Penicillium purourogenum BP110DF.

In the evaluation of the results for growth inhibition of the deteriorative fungus of $B$. archeri (A. niger BA163DF) seeds, no difference was found between the microorganisms with Bacillus sp. BA68EB and B. brevis BA89RB when compared to the control (Table 6).

Table 1. Porcentages of germination, hard seeds, and contamination by fungi and bacteria in Butia purpurascens seeds in different substrates.

\begin{tabular}{|c|c|c|c|c|}
\hline & \multicolumn{2}{|c|}{ Contamination (\%) } & \multirow{2}{*}{ Germination (\%) } & \multirow{2}{*}{ Hard seeds (\%) } \\
\hline & Fungi & Bacteria & & \\
\hline Petri Dish+Paper & $28.5 \pm 7.2 \mathrm{a}^{z}$ & $0.8 \pm 0.8 \mathrm{a}$ & $50.9 \pm 5.1 \mathrm{a}$ & $19.9 \pm 6.5 \mathrm{a}$ \\
\hline Petri Dish +Sand & $30.9 \pm 4.7 \mathrm{a}$ & $17.4 \pm 6.0 \mathrm{~b}$ & $36.2 \pm 7.3 \mathrm{a}$ & $15.5 \pm 5.5 \mathrm{a}$ \\
\hline Paper "Germitest ${ }^{\circledR}$ " & $25.8 \pm 10.5 \mathrm{a}$ & $7.0 \pm 3.0 \mathrm{ab}$ & $34.9 \pm 6.6 \mathrm{a}$ & $32.4 \pm 6.8 \mathrm{a}$ \\
\hline
\end{tabular}

${ }^{\text {z}}$ Means followed by the same letter in the vertical are not significantly by Tukey test $(\mathrm{P}>0.05) . \pm$ Average Standard Error. 
Table 2. Identification of the deteriorative fungi isolates in the Butia purpurascens seeds based on the sequencing of the ITS region.

\begin{tabular}{|c|c|c|c|c|}
\hline $\begin{array}{l}\text { Isolated / } \\
\text { Quantity }\end{array}$ & Identification Blast & $\begin{array}{c}\mathrm{N}^{\mathbf{o}} \text { Access on } \\
\text { GenBank }\end{array}$ & \% Identity & $\begin{array}{c}\text { Relative } \\
\text { Frequency }(\%)\end{array}$ \\
\hline BP202DF (1) & Aspergillus fumigatus & KC119200 & 99 & 1.5 \\
\hline BP209DF (5) & Aspergillus niger & EF175904 & 99 & 7.5 \\
\hline BP131DF (3) & Aspergillus parasiticus & HQ340110 & 99 & 4.5 \\
\hline BP203DF (10) & Aspergillus terreus & GU966497 & 99 & 14.9 \\
\hline BP100DF (9) & Colletotrichum theobromicola & JX010285 & 99 & 13.4 \\
\hline BP206DF (1) & Fusarium avenaceum & FJ478097 & 99 & 1.5 \\
\hline BP139DF (3) & Fusarium concentricum & HQ379635 & 99 & 4.5 \\
\hline BP105DF (1) & Fusarium equiseti & GQ505694 & 99 & 1.5 \\
\hline BP91DF (8) & Neodeightonia phoenicum & HQ443209 & 99 & 11.9 \\
\hline BP125DF (3) & Neosartorya fischeri & AF455541 & 98 & 4.5 \\
\hline BP94DF (2) & Neosartorya spinosa & EF669973 & 99 & 3.0 \\
\hline BP209DF (1) & Paecilomyces variotii & AY753334 & 97 & 1,5 \\
\hline BP125DF (7) & Penicillium pinophilum & FJ441618 & 99 & 10.4 \\
\hline BP110DF (10) & Penicillium purpurogenum & FN868483 & 98 & 14.9 \\
\hline BP104DF (1) & Peyronellaea pomorum & JN003244 & 99 & 1.5 \\
\hline BP127DF (1) & Pleosporales sp. & HQ832821 & 99 & 1.5 \\
\hline BP138DF (1) & Talaromyces amestolkiae & JX965247 & 99 & 1.5 \\
\hline
\end{tabular}

$\mathrm{BP}=$ Butia purpurascens $; \mathrm{D}=$ deteriorative; $\mathrm{F}=$ fungi; ()$=$ total isolates.

Table 3. Identification of the deteriorative fungi isolates in the Butia archeri seeds based on the sequencing of the ITS region.

\begin{tabular}{lllcr}
\hline $\begin{array}{c}\text { Isolated / } \\
\text { Quantity }\end{array}$ & \multicolumn{1}{c}{ Identification Blast } & $\begin{array}{c}\text { No Access on } \\
\text { GenBank }\end{array}$ & \% Identity & $\begin{array}{c}\text { Relative } \\
\text { Frequency (\%) }\end{array}$ \\
\hline BA181DF (1) & Aspergillus flavus & EF409804 & 99 & 2.5 \\
BA163DF (20) & Aspergillus niger & KF304798 & 98 & 50.0 \\
BA142DF (3) & Aspergillus sp. & JF312217 & 99 & 7.5 \\
BA149DF (3) & Aspergillus ustus & AY213638 & 98 & 7.5 \\
BA141DF (2) & Fusarium proliferatum & EU821492 & 99 & 5.0 \\
BA145DF (2) & Gibberella amoniliformis & AB374142 & 98 & 5.0 \\
BA139DF (1) & Gibberella intermedia & JQ272470 & 98 & 2.5 \\
BA170DF (2) & Neodeightonia phoenicum & EU673340 & 98 & 5.0 \\
BA178DF (3) & Penicillium sp. & JQ912017 & 98 & 7.5 \\
BA156DF (3) & Talaromyces sp. & AB808419 & 99 & 7.5 \\
\hline
\end{tabular}

$\mathrm{BA}=$ Butia archeri $; \mathrm{D}=$ deteriorative $; \mathrm{F}=$ fungi; $($ ) = total de isolados.

Table 4. Identification of endophytics and rhizosphere bacteria isolated from roots of Butia purpurascens based on 16S gene sequencing.

\begin{tabular}{llcc}
\hline Isolate & \multicolumn{1}{c}{ Identification Blast } & $\mathbf{N}^{\mathbf{0}}$ Access on GenBank & \% Identity \\
\hline BP35EB & Bacillus methylotrophicus & JF899259 & 99 \\
BP1RB & Bacillus amyloliquefaciens & KC692174 & 99 \\
BP60RB & Bacillus subtilis & DQ517306 & 99 \\
BP66RB & Bacillus amyloliquefaciens & KF483660 & 99 \\
BP70RB & Bacillus amyloliquefaciens & KC692174 & 99 \\
BP71RB & Bacillus amyloliquefaciens & KF483660 & 99 \\
BP186RB & Bacillus subtilis & KF241533 & 99 \\
BP201RB & Bacillus amyloliquefaciens & KC708068 & 98 \\
BA68EB & Bacillus sp. & GQ180177 & 98 \\
BA89EB & Brevibacillus brevis & HM449127 & 99 \\
\hline
\end{tabular}

$\mathrm{BP}=$ Butia purpurascens $; \mathrm{BA}=$ Butia archeri $\mathrm{E}=$ endophytic $; \mathrm{R}=$ rhizospheric $; \mathrm{B}=$ bacteria. 


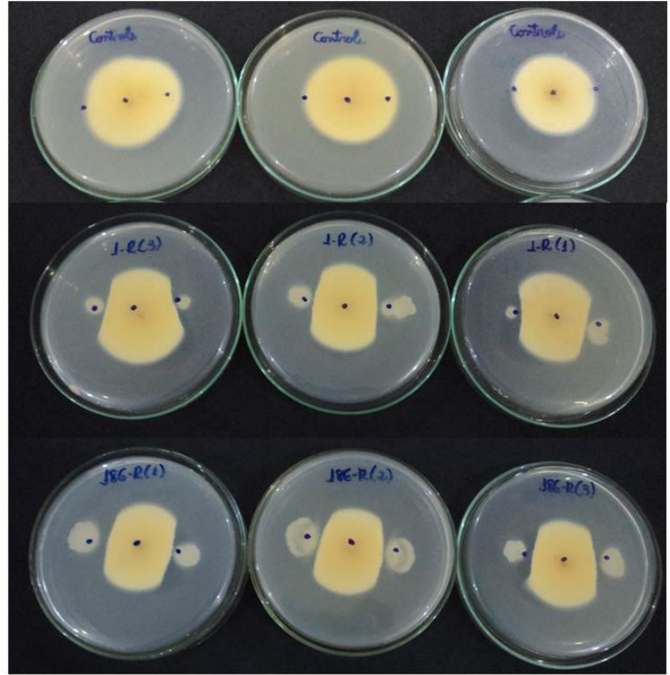

Penicillium purpurogenum BP110DF

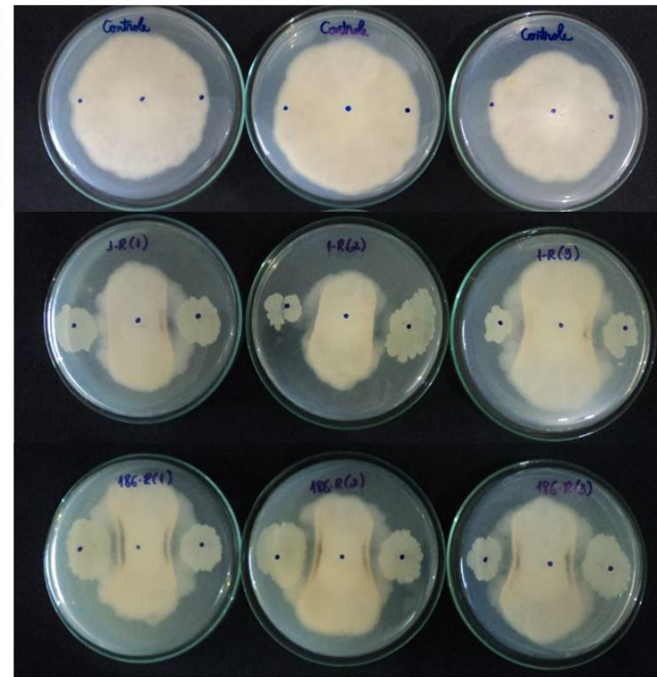

Neodeightonia phoenicum BP91DF

Figure 1. Antibiosis test of isolates of the deteriorative fungi of seeds Penicillium purpurogenum BP110DF and Neodeightonia phoenicum BP91DF with the bacterias Bacillus amyloliquefaciens BP1RB (second line) and Bacillus subtilis BP186RB (third line) and controls (first line).

Table 5. Antibiosis test of the deteriorative fungi isolates (Penicillium purpurogenum and Neodeightonia phoenicum) of the Butia purpurascens seeds.

\begin{tabular}{|c|c|c|}
\hline \multirow{3}{*}{ Treatment } & Penicillium & Neodeightonia \\
\hline & purpurogenum BP110DF & phoenicum BP91DF \\
\hline & \multicolumn{2}{|c|}{ 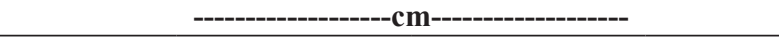 } \\
\hline Control & $4.5^{\mathrm{z}} \mathrm{c}$ & $6.7 \mathrm{~d}$ \\
\hline Bacillus amyloliquefaciens BP1RB & $2.8 \mathrm{ab}$ & $2.9 \mathrm{a}$ \\
\hline Bacillus subtilis BP60RB & $2.5 \mathrm{a}$ & $4.4 \mathrm{c}$ \\
\hline Bacillus amyloliquefaciens BP66RB & $2.8 \mathrm{ab}$ & $3.5 \mathrm{~b}$ \\
\hline Bacillus amyloliquefaciens BP70RB & $2.7 \mathrm{ab}$ & $3.4 \mathrm{~b}$ \\
\hline Bacillus amyloliquefaciens BP71RB & $3.0 \mathrm{~b}$ & $3.5 \mathrm{~b}$ \\
\hline Bacillus subtilis BP186RB & $2.6 \mathrm{ab}$ & $2.5 \mathrm{a}$ \\
\hline Bacillus amyloliquefaciens BP201RB & $2.3 \mathrm{ab}$ & $3.6 \mathrm{~b}$ \\
\hline Bacillus methylotrophicus BP35EB & $2.8 \mathrm{ab}$ & $3.7 \mathrm{~b}$ \\
\hline
\end{tabular}

${ }^{\mathrm{z}}$ Means followed by the same letter in the column are not significantly by Tukey test $(\mathrm{P}>0.05)$. \pm Average Standard Error.

Table 6. Antibiosis test of the deteriorative fungi isolates (Aspergillus niger) of the Butia archeri seeds.

\begin{tabular}{lc}
\hline \multirow{1}{*}{ Treatment } & $\begin{array}{c}\text { Aspergillus niger } \\
\text { BA163DF }\end{array}$ \\
\cline { 2 - 2 } & -------cm-------- \\
\hline Control & $5.95^{\mathrm{z}} \mathrm{a}$ \\
Bacillus sp. BA68EB & $5.85 \mathrm{a}$ \\
Brevibacillus brevis BA89RB & $5.1 \mathrm{a}$ \\
\hline
\end{tabular}

${ }^{2}$ Means followed by the same letter in the column are not significantly by Tukey test $(\mathrm{P}>0.05)$.

\subsection{Microbiolization of Butia purpurascens and Butia archeri seeds}

In the microbiolization of B. purpurascens and $B$. archeri seeds using endophytic and rhizospheric strains of Bacillus sp., no differences were found in the percentages of germination and contamination by fungi, the latter of which varied between 19.3 to $39.3 \%$ (Table 7). There was also no difference between the solutions for seed germination, varying from 24.3 to $41.0 \%$ for the yatay palm.

Contamination by fungi and bacteria was noted for B. archeri after one day of cultivation, mainly in the regions of lesions caused by the extraction and the scarification process. We observed that initially there was intense release of seed exudates, followed by fungal contamination. However, there was no difference in fungal and bacterial contamination between bacterial treatments, which varied between $60 \%$ and $63.3 \%$.

A low percentage of germination was found, with a minimum of $16.6 \%$ and maximum of $22.5 \%$. There was no difference in germination efficiency between the bacteria evaluated to control the contamination during the evaluated period (Figure 2). 
Table 7. Percentage of germination and contamination in Butia purpurascens seeds treated with different inoculants.

\begin{tabular}{lcc}
\hline & Germination (\%) & Contamination (\%) \\
\hline Control & $26.7^{\mathrm{z}} \pm 16.0$ & $41.0 \pm 8.2$ \\
Bacillus amyloliquefaciens BP1RB & $39.3 \pm 16.6$ & $26.7 \pm 6.1$ \\
Bacillus amyloliquefaciens BP70RB & $25.1 \pm 6.1$ & $31.3 \pm 8.2$ \\
Bacillus subtilis BP186RB & $23.6 \pm 5.3$ & $29.3 \pm 5.6$ \\
Bacillus methylotrophicus BP35EB & $19.3 \pm 3.5$ & $24.3 \pm 3.3$ \\
\hline
\end{tabular}

${ }^{\mathrm{z}}$ Means followed by the same letter in the column are not significantly by Tukey test $(\mathrm{P}>0.05)$.

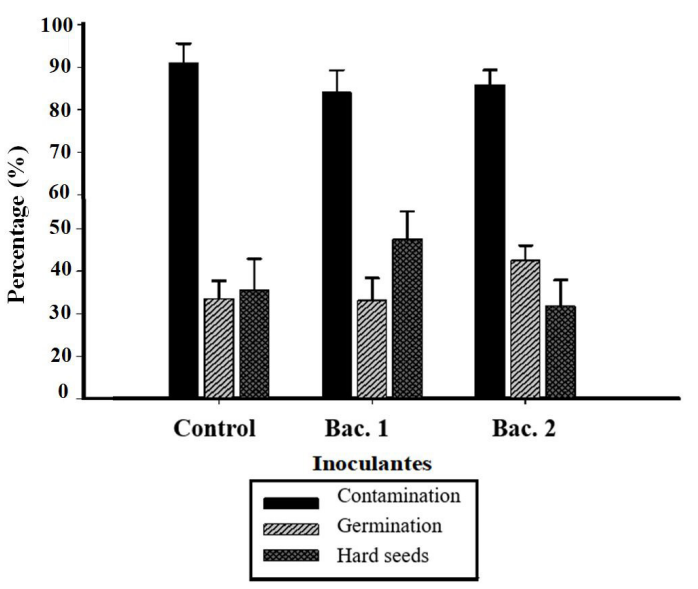

Figure 2. Percentage of germination, hard seeds and contamination by fungi in Butia archeri seeds treated with different inoculants. Control $=$ Nutrient broth; Bac. $1=$ Nutrient broth plus endophytic bacteria; Bac. 2 = Nutritious broth plus rhizosphere bacterium.

\section{Discussion}

The results observed in this study for the percentage of germination of $B$. purpurascens seeds in different substrates was lower than that observed by Fior et al. (2011) with Butia capitata (Martius) Beccari seeds, which reached 90\% germination when kept in Gerbox plastic boxes containing autoclaved sand for 150 days. The germination of wax palm (Copernicia alba Morong.) seeds was also favored: it reached $67 \%$ when sowed on paper at a temperature between 20 and $30^{\circ} \mathrm{C}$ (Masetto et al., 2012). Rubio Neto et al. (2014) obtained 63.8\% germination of Acrocomia aculeata (Jacq.) Lood. ex Mart. seeds when they were scarified and kept on rolls of Germitest ${ }^{\circledR}$ paper.

In this study, the seeds were not immersed in a gibberellic acid solution, which is an alternative to increase the germination percentages of seeds with physiological dormancy. Studies consider immersing the seeds in a gibberellic acid solution and removing the opercular tegument to be an alternative method that can promote increased germination in macaw palm seeds (Oliveira et al., 2013; Rodrigues Junior et al., 2013).

For the B. purpurascens seeds, the bacterial isolate B. subtilis BP186RB showed the best capacity for suppressing the growth of Neodeightonia phoenicum BP91DF and
Penicillium purpurogenum BP110DF, the two deteriorative fungi tested. However, for $B$. archeri seeds, no difference were observed between the microorganisms with Bacillus sp. BA68EB and B. brevis BA89RB compared to the control in inhibiting the growth of deteriorative fungi.

Bacillus sp. are capable of synthesizing a structurally diverse group of antimicrobial compounds of low molecular weight that suppress phytopathogens and cyclic peptide derivatives, especially lipopeptides (Kilimushi et al., 2017). Gond et al. (2015), through a MALDI-TOF-MS analysis, identified antifungal groups such as surfactin, iturin, and fengycin that exhibited strong antibacterial activity, consequently inhibiting the growth of filamentous fungi by antagonizing sterols, phospholipids, and oleic acid in fungal membranes, thereby protecting against pathogenic agents.

Song et al. (2014) performed a study for controlling ginseng root rot, caused by the fungus Fusarium, through the use of B. amyloliquefaciens. The study showed, through scanning electron microscopy, that the hyphae of the pathogen were twisted and withered with bacterial treatment, which can be a symptom of direct damage by antifungal substances.

In the microbiolization of $B$. purpurascens and $B$. archeri seeds performed with microbiological solutions produced based on endophytic and rhizospheric strains of Bacillus sp., no differences were observed in the percentages of germination and contamination by fungi.

For $B$. archeri, there was contamination by fungi and bacteria after one day of cultivation, mainly in the regions with lesions caused by the extraction and scarification process.

This is the first study for B. purpurascens and B. archeri that shows major problems with contamination during germination, exhibiting low percentages of normal seedlings. However, further studies should be carried out to further validate the use of biological control in these species.

\section{Acknowledgments}

The authors thank the Coordenação de Aperfeiçoamento de Pessoal de Nível Superior (CAPES), the Conselho Nacional de Desenvolvimento Científico e Tecnológico $(\mathrm{CNPq})$, the Fundação de Amparo à Pesquisa do Estado de Goiás (FAPEG) and the Instituto Federal Goiano, Campus Rio Verde for providing financial support to this work. 


\section{References}

BENÍTEZ, T., RINCÓN, A.M., LIMÓN, C.M. and CODÓN, A.C., 2004. Biocontrol mechanisms of Trichoderma strains. International Microbiology, vol. 7, no. 4, pp. 249-260. PMid:15666245.

BOZZA, A.F.O., 2009. Determinação de metais essenciais na polpa do fruto Butia purpurascens Glassman e sua utilização em mistura em pó para bolo. Goiânia: Universidade Católica de Goiás, 74 p. Dissertação de Mestrado em Ecologia e Produção Sustentável.

CHENG, H.R. and JIANG, N., 2006. Extremely rapid extraction of DNA from bacteria and yeasts. Biotechnology Letters, vol. 28, no. 1, pp. 55-59. http://dx.doi.org/10.1007/s10529-005-4688-z. PMid:16369876.

DUN, I.S. and BLATTNER, F.R., 1987. Charons 36 to 40: multienzyme, high capacity, recombination deficient replacement vectors with polylinkers and polystuffers. Nucleic Acids Research, vol. 15 , no. 6, pp. 2677-2698. http://dx.doi.org/10.1093/ nar/15.6.2677. PMid:3031608.

FIOR, C.S., RODRIGUES, L.R., LEONHARDT, C. and SCHWARZ, S.F., 2011. Superação de dormência em sementes de Butia capitata. Ciência Rural, vol. 41, no. 7, pp. 1150-1153. http://dx.doi.org/10.1590/S0103-84782011005000087.

GOND, S.K., BERGEN, M.S., TORRES, M.S. and WHITE JUNIOR, J.F., 2015. Endophytic Bacillus spp. produce antifungal lipopeptides and induce host defence gene expression in maize. Microbiological Research, vol. 172, pp. 79-87. http://dx.doi. org/10.1016/j.micres.2014.11.004. PMid:25497916.

GUSMÃO, E., VIEIRA, F.A. and FONSECA, E.M., 2006 [viewed 18 July 2019]. Biometria de frutos e endocarpos de murici (Byrsonima verbascifolia Rich. Ex. A. Juss). Cerne [online], vol. 12, pp. 84-91. Available from: https://www.redalyc.org/ $\mathrm{html} / 744 / 74412110 /$

HOFFMANN, J.F., BARBIERI, R.L., ROMBALDI, C.V. and CHAVES, F.C., 2014. Butia spp. (Arecaceae): an overview. Scientia Horticulturae, vol. 179, pp. 122-131. http://dx.doi. org/10.1016/j.scienta.2014.08.011.

INTERNATIONAL UNION FOR CONSERVATION OF NATURE - IUCN, 2011 [viewed 18 July 2019]. The IUCN Red List of Threatened Species. Version 2019-2 [online]. Gland. Available from: http://www.iucnredlist.org

KILIMUSHI, P.Z., ARIAS, A.A., FRANZIL, L., STEELS, S. and ONGENA, M., 2017. Stimulation of fengycin-type antifungal lipopeptides in Bacillus amyloliquefaciens in the presence of the maize fungal pathogen Rhizomucor variabilis. Frontiers in Microbiology, vol. 8, pp. 850. PMid:28555132.

LIU, K., MCINROY, J.A., HU, C.H. and KLOEPPER, J.W., 2018. Mixtures of plant-growth-promoting Rhizobacteria enhance biological control of multiple plant diseases and plant-growth promotion in the presence of pathogens. Plant Disease, vol. 102, no. 1, pp. 67-72. http://dx.doi.org/10.1094/PDIS-04-17-0478-RE. PMid:30673446.

LORENZI, H., KAHN, F., NOBLICK, L.R. and FERREIRA, E., 2010. Flora brasileira: Arecaceae (Palmeiras). Nova Odessa: Instituto Plantarum, $368 \mathrm{p}$.

MAGALHÃES, H.M., CATÃO, H.C.R.M., SALES, N.L.P., LIMA, N.F. and LOPES, P.S.N., 2008. Qualidade sanitária de sementes de coquinho-azedo (Butia capitata) no Norte de Minas
Gerais. Ciência Rural, vol. 38, no. 8, pp. 2371-2374. http://dx.doi. org/10.1590/S0103-84782008000800045.

MASETTO, T.E., SCALON, S.P.Q., BRITO, J.Q., MOREIRA, F.H., RIBEIRO, D.M. and REZENDE, R.K.S., 2012. Germinação e armazenamento de sementes de carandá (Copernicia alba). Cerne, vol. 18, no. 4, pp. 541-546. http://dx.doi.org/10.1590/ S0104-77602012000400003.

MELO, I.S. and AZEVEDO, J.L., 1998. Controle biológico. Jaguariúna: EMBRAPA, 262 p.

MEW, T.W. and ROSALES, A.M., 1986. Bacterization of rice plants for control of sheath blight caused by Rhizoctonia solani. Phytopathology, vol. 76, no. 11, pp. 1260-1264. http://dx.doi. org/10.1094/Phyto-76-1260.

MYERS, N., MITTERMEIER, R.A., MITTERMEIER, C.G., FONSECA, G.A.B. and KENT, J., 2000. Biodiversity hotspots for conservation priorities. Nature, vol. 403, no. 6772, pp. 853-858. http://dx.doi.org/10.1038/35002501. PMid:10706275.

NATIONAL CENTER FOR BIOTECHNOLOGY INFORMATION - NCBI [online], 2019 [viewed 2 April 2019]. Available from: http://www.ncbi.nlm.nih.gov

O'BRIEN, H.E.O., PARRENT, J.L., JACKSON, J.A., MONCALVO, J. and VILGALYS, R., 2005. Fungal community analysis by large-scale sequencing of environmental samples. Applied and Environmental Microbiology, vol. 71, no. 9, pp. 5544-5550. http:// dx.doi.org/10.1128/AEM.71.9.5544-5550.2005. PMid:16151147.

OLIVEIRA, T.G.S., RODRIGUES-JUNIOR, A.G., SOUZA, P.P. and RIBEIRO, L.M., 2013. Use of phytoregulators in overcoming macaw palm seed dormancy. Acta Scientiarum: Agronomy, vol. 35, no. 4, pp. 505-511. http://dx.doi.org/10.4025/actasciagron. v35i4.16385.

REMUSKA, A.C. and PRIA, D.M., 2007. Efeito de Bacillus thuringiensis e Trichoderma sp. no crescimento de fungos fitopatogênicos. Publicatio UEPG: Ciências Exatas e da Terra, Ciências Agrárias e Engenharias, vol. 13, pp. 31-36. http://dx.doi. org/10.5212/publicatio.v13i03.893.

ROCHA, R., LUZ, D.E., ENGELS, C., PILEGGI, S.A.V., JACCOUD FILHO, D.S., MATIELLO, R.R. and PILEGGI, M., 2009. Selection of endophytic fungi from comfrey (Symphytum officinale L.) for in vitro biological control of the Phytopathogen sclerotinia sclerotiorum (Lib.). Brazilian Journal of Microbiology, vol. 40, no. 1, pp. 73-78. http://dx.doi.org/10.1590/S151783822009000100011. PMid:24031320.

RODRIGUES-JUNIOR, A.G., OLIVEIRA, T.G.S., SOUZA, P.P. and RIBEIRO, L.M., 2013. Water uptake and pre-germination treatments in macaw palm (Acrocomia aculeata-Arecaceae) seeds. Journal of Seed Science, vol. 35, no. 1, pp. 99-105. http://dx.doi. org/10.1590/S2317-15372013000100014.

RUBIO NETO, A., SILVA, F.G., SALES, J.F., REIS, E.F., SILVA, L.Q. and CAMPOS, R.C., 2014. Dormancy breaking in macaw palm [Acrocomia aculeata (Jacq.) Loddiges ex Mart.] seeds. Acta Scientiarum: Agronomy, vol. 36, no. 1, pp. 43-50. http://dx.doi. org/10.4025/actasciagron.v36i1.13220.

RUBIO NETO, A., SILVA, F.G., SALES, J.F., REIS, E.F., SILVA, M.V.V. and SOUZA, A.L., 2012. Effect of drying and soaking fruits and seeds on germination of macaw palm (Acrocomia aculeata [Jacq.] Loddiges ex MART.). Acta Scientiarum: Agronomy, vol. 34, no. 2, pp. 179-185. http://dx.doi.org/10.4025/actasciagron. v34i2.11752. 
SAITO, K., WATANABE, M., MATSUI, H., YAMAMOTO, M., ICHINOSE, Y., TOYODA, K., KAWAGUCHI, A. and NOUTOSHI, Y., 2018. Characterization of the suppressive effects of the biological control strain VAR03-1 of Rhizobium vitis on the virulence of tumorigenic $R$. vitis. Journal of General Plant Pathology, vol. 84, no. 1, pp. 58-64. http://dx.doi.org/10.1007/ s10327-017-0756-1.

SONG, M., YUN, H.Y. and KIM, Y.H., 2014. Antagonistic Bacillus species as a biological control of ginseng root rot caused by Fusarium cf. incarnatum. Journal of Ginseng Research, vol. 38, no. 2, pp. 136-145. http://dx.doi.org/10.1016/j.jgr.2013.11.016. PMid:24748838.

WEISBURG, W.G., BARNS, S.M., PELLETIER, D.A. and LANE, D.J., 1991. 16S ribosomal DNA amplification for phylogenetic study. Journal of Bacteriology, vol. 173, no. 2, pp. 697-703. http://dx.doi.org/10.1128/JB.173.2.697-703.1991. PMid:1987160.

WHITE, T.J., BRUNS, T., LEE, S. and TAYLOR, J. 1990. Amplification and direct sequencing of fungal ribosomal RNA genes for phylogenetics. In: M.A. INNIS, D.H. GELFAND, J.J. SNINSKY and T.J. WHITE, eds. PCR Protocols: a guide to methods and applications. New York: Academic Press, pp. 315-322.

YUAN, Y., FENG, H., WANG, L., LI, Z., SHI, Y., ZHAO, L., FENG, Z. and ZHU, H., 2017. Potential of endophytic fungi isolated from cotton roots for biological control against verticillium wilt disease. PLoS One, vol. 12, no. 1, pp. e0170557. http://dx.doi. org/10.1371/journal.pone.0170557. PMid:28107448. 